\title{
Correction to: Increasing the synthesis of bioactive abietane diterpenes in Salvia sclarea hairy roots by elicited transcriptional reprogramming
}

\author{
M. C. Vaccaro ${ }^{1} \cdot$ M. Alfieri ${ }^{1} \cdot$ N. Malafronte ${ }^{1} \cdot$ N. De Tommasi ${ }^{1} \cdot$ A. Leone $^{1}$
}

Published online: 10 August 2018

๑) Springer-Verlag GmbH Germany, part of Springer Nature 2018

Correction to: Plant Cell Rep (2017) 36:375-386

https://doi.org/10.1007/s00299-016-2076-x

Unfortunately, the second author name was wrongly published in the original publication. The correct author name should read as follows:

Mariaevelina Alfieri. 